\title{
Interaction of metabolic and haemodynamic factors in mediating experimental diabetic nephropathy
}

\section{M.E.Cooper}

Department of Medicine, University of Melbourne, Austin and Repatriation Medical Centre (Repatriation Campus), Heidelberg West, Victoria, Australia

\section{Abstract}

Diabetic nephropathy seems to occur as a result of an interaction of metabolic and haemodynamic factors. Glucose dependent pathways are activated within the diabetic kidney. These include increased oxidative stress, renal polyol formation and accumulation of advanced glycated end-products. Haemodynamic factors are also implicated in the pathogenesis of diabetic nephropathy and include increased systemic and intraglomerular pressure and activation of various vasoactive hormone pathways including the renin-angiotensin system and endothelin. These haemodynamic pathways, independently and with metabolic pathways, activate intracellular second messengers such as protein kinase $\mathrm{C}$ and MAP kinase, nuclear transcription factors such as NF- $\varkappa \mathrm{B}$ and various growth factors such as the prosclerotic cytokine, TGF- $\beta$ and the angiogenic, permeability enhancing growth factor, VEGF. These pathways ultimately lead to increased renal albumin permeability and extracellular matrix accumulation which results in increasing proteinuria, glomerulosclerosis and tubulointerstitial fibrosis. Therapeutic strategies involved in the management and prevention of diabetic nephropathy include currently available treatments such as intensified glycaemic control and antihypertensive agents, particularly those which interrupt the renin-angiotensin system. More novel strategies to influence vasoactive hormone action or to inhibit various metabolic pathways such as inhibitors of advanced glycation, specific protein kinase $\mathrm{C}$ isoforms and aldose reductase are at present under experimental and clinical investigation. It is predicted that multiple therapies will be required to reduce the progression of diabetic nephropathy. [Diabetologia (2001) 44: 1957-1972]

Keywords Protein kinase C, nephropathy angiotensin II, endothelin, glycation, VEGF, TGF $\beta$, CTGF, hypertension, nephrin.
Corresponding author: M. E. Cooper, Department of Medicine, University of Melbourne, Austin and Repatriation Medical Centre (Repatriation Campus), Heidelberg West, Victoria 3081, Australia, e-mail: cooper@austin.unimelb.edu.au

Abbreviations: PKC, protein kinase C; SHR, spontaneously hypertensive rat; RAS, renin-angiotensin system; $N F-\varkappa \mathrm{B}$, nuclear factor-kappa B; AII, angiotensin II; AT1, angiotensin type 1 receptor; AT2, angiotensin type 2 receptor; NEP, neutral endopeptidase; NOS, nitric oxide synthase; RAGE, receptor for advanced glycation end-products; VEGF, vascular endothelial growth factor; PDGF, platelet derived growth factor; GFAT, glutamine:fructose-6-phosphate amidotransferase; ROS, reactive oxygen species; MAPK, mitogen-activated protein kinase; HMG, hydroxymethylglutaryl; CTGF, connective tissue growth factor; VEGF-R2, vascular endothelial growth factor receptor 2
As the prevalence of diabetic nephropathy increases it has become increasingly urgent to determine the pathophysiological mechanisms responsible for this disorder. This will allow more rational strategies to be developed to prevent, retard or reverse this condition. The major clinical associations with diabetic nephropathy (DN) are hyperglycaemia and hypertension $[1,2]$. Our own group has been exploring the links between metabolic and haemodynamic factors in mediating diabetic renal disease (Fig. 1) [3]. This seems to involve a range of growth factors as reviewed recently [4], intracellular signalling molecules and nuclear transcription factors that lead to the classical functional and structural hallmarks of DN, albuminuria and extracellular matrix accumulation. This 


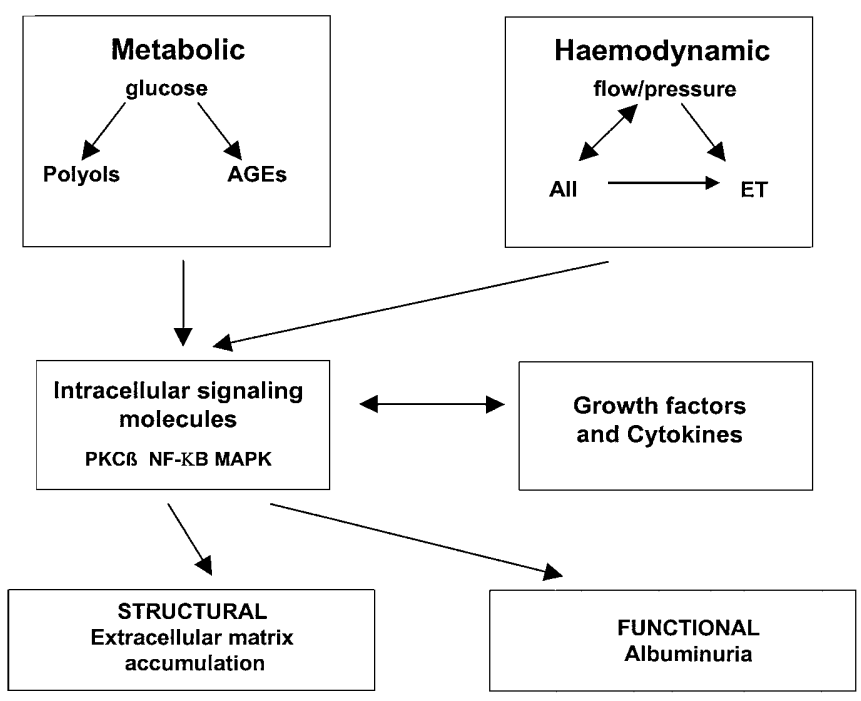

Fig. 1. Schema outlining interactions among haemodynamic factors, metabolic pathways, cytokines and intracellular signalling molecules in mediating diabetic nephropathy. Adapted and revised from [36]

review will summarise important pathways implicated in $\mathrm{DN}$, describe potential sites of interaction among these pathways and explore therapeutic options, both current and pending, which interrupt these pathophysiological processes within the kidney.

Much of the work described below has used experimental models of diabetic nephropathy, particularly in rodents. This includes not only the use of genetic models of diabetes but specifically models which involve the induction of diabetes with pancreatic betacell specific toxins such as streptozotocin [5]. These models show most of the functional and structural features of DN including increases in GFR, albuminuria and glomerular ultrastructural injury including glomerular hypertrophy, mesangial expansion and glomerular basement membrane thickening. Initially most studies were carried out in models of Type I (insulin-dependent) diabetes mellitus but increasingly experiments are also being carried out in models of Type II diabetes such as the obese Zucker rat [6] and various genetic models of type II diabetes in the mouse [7]. When compared to human DN these models lack considerable tubulointerstitial injury or renal impairment. Other models however, have been evaluated recently and show some of these additional abnormalities $[8,9]$.

\section{Haemodynamic factors}

A range of studies by our group showed the importance of systemic hypertension in accelerating renal injury in diabetes [10]. In a model combining genetic hypertension with streptozotocin diabetes, the diabetic spontaneously hypertensive rat (SHR), com- parisons on both functional and structural markers of DN were made with normotensive Wistar Kyoto rats with diabetes. Hypertension was associated with increased albuminuria and a further increase in glomerular basement membrane thickening. Furthermore, a range of studies using different antihypertensive agents in diabetic SHR were associated with attenuation of the rise in albuminuria and improvement in various glomerular morphological parameters [11].

Renin-angiotensin system (RAS). The landmark studies by Brenner's group emphasised the role of haemodynamic factors in DN, particularly the potential of inhibitors of the RAS as renoprotective agents in experimental diabetes [12]. Micropuncture studies in diabetic rats showed a range of intrarenal haemodynamic abnormalities including increased intraglomerular pressure, increased single nephron GFR and preferential afferent compared with efferent arteriolar vasodilatation [12]. This increase in intraglomerular pressure was considered to play a pivotal role in mediating progressive glomerular injury in a range of renal diseases including diabetes [13]. This hypothesis was partly based on findings whereby intraglomerular pressure was reduced by a range of treatments including ACE inhibitors [12] and low protein diets [14] associated with reduced renal injury. This central role for intraglomerular hypertension extended our understanding of the importance of haemodynamic factors in mediating renal injury in diabetes. It emphasised that determinants of progression of DN included not only systemic hypertension but also intrarenal haemodynamic changes which could occur even in the setting of a normal blood pressure [12].

To further explore the role of the RAS in mediating progressive renal injury, a number of studies were done on the Ren 2 rat, a model which introduces the murine renin gene into the rat genome [15]. These animals show increased expression of various components of the RAS particularly outside the kidney and develop systemic hypertension. Diabetes was induced in heterozygous Ren 2 rats and this was associated with rapid development of glomerular and tubulointerstitial changes and a decline in renal function within 12 weeks [8]. These functional and structural changes could be attenuated by agents which block the RAS including ACE inhibitors and angiotensin II (AII) receptor antagonists $[8,16]$. Despite a similar reduction in systemic blood pressure, endothelin receptor blockade, did not confer a similar degree of renal protection to agents which interrupt the RAS suggesting that much of the damage in this model is AII dependent [16].

The status of the RAS in diabetes remains controversial. In general, plasma measurements of various components of the RAS are low or normal in diabe- 
tes [17]. However, it is well appreciated that the RAS also acts locally within the kidney with all components including enzymes and receptors present within the kidney. Measurements of the various components of the RAS within the kidney by a range of techniques have been contradictory with reports of reduced, normal or decreased expression of renin and AII in the diabetic kidney [18-20]. In vitro studies in proximal tubular cells have described increased angiotensinogen expression in response to glucose [21]. In mesangial cells, hyperglycaemia has also been reported to stimulate angiotensin II production in association with increased TGF- $\beta$ production [22].

It is possible that rather than a uniform change in these components within the kidney there is primarily a change in the distribution of these proteins within the various compartments of the kidney. For example, in experimental diabetes a redistribution of ACE to vascular and glomerular sites in diabetes was reported [18]. In the model of subtotal nephrectomy, which has functional and structural similarities to $\mathrm{DN}$, we observed increased proximal tubular renin expression which was attenuated by ACE inhibitor treatment [23]. More recently, we have documented a similar phenomenon in diabetic Ren 2 rats with renin expression particularly in damaged tubules which was reduced at the site by an AII receptor antagonist in the context of an increase in renin expression at the major site of synthesis, the juxtaglomerular apparatus [16]. This increase in proximal tubular renin was associated with increased expression of AII, the effector peptide of the RAS which mediates a range of haemodynamic and non-haemodynamic effects (see below). Further evidence for the local activation of the RAS in the tubular compartment has been suggested in studies measuring tubular renin by RTPCR. In those studies there was an early increase in proximal tubular renin in experimental diabetes [24]. The authors postulated that this could contribute to a local increase in AII resulting in tubulointerstitial fibrosis in this model. These findings emphasise changes in the distribution of the RAS in the diabetic kidney which could be important in mediating progressive renal injury. Another important explanation for the disparity in the various measurements of both the systemic and intrarenal RAS in diabetes and the responsiveness of the diabetic kidney to blockade of the RAS could relate to increased sensitivity of the diabetic kidney to AII [25].

Although AII has haemodynamic effects both systemically and within the kidney, it is becoming increasingly evident that AII has a range of nonhaemodynamic effects relevant to progressive renal injury [26]. It has been difficult to separate the haemodynamic from its non-haemodynamic effects in vivo but the use of cultured cells has allowed investigators to explore these additional effects of AII. AII induces extracellular matrix accumulation, a hallmark of DN primarily through stimulation of the prosclerotic cytokine, TGF $\beta$ [27]. Indeed, a range of studies has shown that inhibition of the RAS in both non-diabetic and diabetic models of renal injury is associated with reduced renal TGF $\beta$ expression, particularly in the tubulointerstitium [28, 29]. AII could also influence a range of other cytokines and in particular it could activate a range of intracellular mediators implicated in progressive renal injury such as protein kinase $\mathrm{C}$ [30] and the nuclear transcription factor, nuclear factor kappa $\mathrm{B}(\mathrm{NF}-$ xB) [31].

AII also influences cell growth, proliferation and apoptosis via a range of pathways not yet fully defined $[32,33]$. In particular, AII-induced effects on cell cycle regulation could be relevant to various changes in the diabetic kidney including renal hypertrophy [32]. The reduction in glomerular hypertrophy which is often observed with blockade of the RAS [34] might partly relate to effects on cell cycle regulation. For example, treatment of diabetic rats with ACE inhibitors was associated not only with reduced glomerular volume but also abolition of glomerular expression of the cyclin-dependent kinase inhibitors $\mathrm{p}^{16 \mathrm{INK} 4}$ and $\mathrm{p}^{27 \mathrm{Kip} 1}$ [35]. These actions of AII might be central to how haemodynamic pathways interact with metabolic and glucose dependent factors in accelerating DN.

ACE inhibitors have clearly been shown to confer renoprotective effects, initially in experimental models but ultimately in human DN [36]. These beneficial effects relate to the capacity of these agents to reduce blood pressure and to block AII formation. Although ACE inhibitors have other effects including inhibition of degradation of kinins, experimental studies using bradykinin and angiotensin II receptor antagonists indicate that the long-term renal protection given by these agents is mostly via the inhibition of AII dependent pathways [34]. The advent of selective AII receptor antagonists has now allowed investigators to explore the specific role of AII in mediating renal injury and provides a new approach for conferring renal protection in diabetic patients.

AII interacts with two specific receptors known as the angiotensin type 1 (AT1) and angiotensin type 2 (AT2) receptor subtypes. It is generally viewed that most of the actions of AII are via the AT1 receptor including its haemodynamic and prosclerotic effects. More recent studies of the role of the AT2 receptor have suggested that this receptor could also play a role in the kidney [37] although this issue has not been adequately characterised in the diabetic kidney. Changes in expression of the AII receptors in the diabetic kidney have been reported but the functional significance of these changes is not known [25]. Selective blockers of both receptor subtypes have been developed. However, long-term studies have only reported on blockers of the AT1 receptor subtype indi- 
cating that these agents are renoprotective in experimental and human DN [34, 38-40].

Although ACE inhibitors afford a degree of renal protection, DN continues to progress relentlessly albeit at a slower rate [41]. It has been suggested that a more effective blockade of the effects of AII will occur by both blocking its synthesis with an ACE inhibitor and reducing its action via blockade at the receptor with an AII receptor antagonist [42]. In recent experimental studies, we documented that this combination in diabetic SHR and in diabetic Ren2 rats was associated with increased hypotensive efficacy and less albuminuria [43, 44]. Similar effects on blood pressure and renal functional parameters of the combination have been reported in various stages of human DN [42].

Other vasoactive hormones. In addition to the RAS, various other vasoactive hormones have been postulated to mediate progressive renal injury [45]. Intrarenal as well as systemic haemodynamics are influenced by a balance of vasoconstrictors and vasodilators. These substances include hormones which have different effects on afferent and efferent arteriolar tone, thereby having disparate actions on intraglomerular pressure. Important vasoconstrictors to consider in addition to AII within the kidney are the endothelins [46] and vasopressin [47]. In addition, a range of vasodilatory substances including bradykinin, atrial natriuretic factor, certain prostaglandins and nitric oxide modulate glomerular vasomotor tone [48].

The formation and degradation of many of these vasoactive hormones rely on zinc dependent metallopeptidases, the most well known example being ACE. Other enzymes include neutral endopeptidase (NEP) which plays an important role in the degradation of natriuretic peptides as well as bradykinin and endothelin converting enzyme (ECE) which is involved in endothelin formation [48]. Because these zinc dependent metallopeptidases have significant homology, pharmaceutical companies have developed molecules which act to inhibit more than one of these enzymes [49]. A major target has been the inhibition of ACE and NEP leading to reduced degradation of vasodilatory hormones and reduced formation of the vasoconstrictor hormone, AII. This approach would theoretically lead to increased vasodilation resulting in greater antihypertensive efficacy and potentially superior renoprotection than would be obtained with ACE inhibition alone. Such agents have now been explored in preclinical and clinical contexts. In the subtotal nephrectomy model, several groups have reported renoprotective effects of the dual ACE/NEP inhibitor, omapatrilat [50]. In a short-term study in the diabetic SHR, our group has shown with another ACE/NEP inhibitor antihypertensive efficacy in association with beneficial effects on urinary albumin excretion [51].
A number of selective antagonists to receptors of the vasoconstrictor hormones, endothelin and vasopressin have also been developed [46, 47]. The role of these agents as renoprotective therapies in diabetes remains to be clarified. Endothelin-1 expression has been reported to be increased in the diabetic kidney [52]. Various changes in endothelin receptor subtypes have also been reported [53]. The findings are not consistent in terms of renoprotection with endothelin receptor blockade in diabetic and non-diabetic models of renal injury [54, 55]. This could relate to the nature of the renal disease, sodium balance, pharmacological characteristics of the various receptor antagonists and the selectivity of these compounds for the endothelin type $\mathrm{A}\left(\mathrm{ET}_{\mathrm{A}}\right)$ and the endothelin type $\mathrm{B}\left(\mathrm{ET}_{\mathrm{B}}\right)$ receptor subtypes [56].

Nitric oxide. Although exploration of haemodynamic pathways in diabetes has focussed on vasoactive hormones, one cannot exclude a role for nitric oxide, a potent vasodilator which influences glomerular vasomotor tone [57]. The status of the nitric oxide pathway in diabetes seems to be organ and duration specific with evidence of nitric oxide deficiency in the macrovascular tree with increasing duration of diabetes [58]. In contrast, it has been considered that in the diabetic kidney there are increased nitric oxide concentrations and/or action $[59,60]$.

Initial studies in the kidney suggested increased nitric oxide concentrations in the diabetic kidney, based on the relatively crude marker of urinary nitrate and nitrite production [59]. Further studies on this increase of nitric oxide were based on experiments using nonselective inhibitors of nitric oxide synthase (NOS) which showed reductions in GFR and renal plasma flow in hyperfiltering diabetic rats [68]. Recent studies suggest that a major abnormality in the diabetic kidney is increased expression of endothelial NOS $[61,62]$ with several groups reporting no change in inducible NOS (iNOS) [61, 63]. This contrasts with initial studies suggesting a possible role for iNOS in diabetic nephropathy and diabetic hyperfiltration in particular. Indeed, in a recent study, administration of a selective iNOS inhibitor, L-imino-ethyl-lysine failed to influence renal function in diabetic rats [61].

The situation could be even more complex in diabetes evident from differing results on the various nitric oxide synthase isoforms from several studies. This could relate to different techniques for assessing the various nitric oxide synthase isoforms. For example, using RT-PCR, no changes in either endothelial or inducible nitric oxide synthase were observed [64]. However, when localisation of endothelial nitric oxide synthase was assessed, specific upregulation was observed in the afferent arteriole which was postulated to be involved in the development of diabetes associated glomerular hyperfiltration [62]. Evaluation of neuronal nitric oxide synthase has suggested 
reduced expression of this isoform in the macula densa as assessed histochemically using NADPH diaphorase $[65,66]$.

It remains to be determined if these effects of nitric oxide on early renal haemodynamic abnormalities are of any long-term relevance, particularly to the development of renal impairment and ultrastructural injury in diabetes. Our studies using the nonspecific inhibitor of nitric oxide synthase, L-NAME, did not clearly show renoprotection [63]. Of interest, there was a tendency for a reduction in renal advanced glycated end products (AGE) formation and this could partly relate to the role of nitric oxide in inducing oxidative stress via production of peroxynitrite [67].

\section{Metabolic pathways}

Advanced glycation. AGEs are generated as a result of a series of sequential biochemical reactions, some of which are poorly defined, involving nonenzymatic glycation of protein and lipids [68]. This process also involves oxidation reactions; therefore AGEs can be considered 'glycoxidation' products [69]. These AGEs are increased in diabetes due to chronic hyperglycaemia. Some of these AGEs have been identified chemically and include carboxymethyllysine [70] and pentosidine [71]. In experimental diabetic nephropathy there is renal accumulation of AGEs [72]. These AGEs were evaluated initially, based on their characteristic fluorescence [72]. In studies on diabetic mice, renal AGE accumulation was found which could be attenuated by either pancreatic islet transplantation or treatment with an inhibitor of AGE formation, aminoguanidine [73].

Subsequently, our group evaluated the role of aminoguanidine in diabetic rats and showed that reduced renal AGE accumulation with this drug was associated with retardation in the development of albuminuria and attenuation of mesangial expansion [72]. Since advanced glycation end products accumulate over time, we explored the role of early versus delayed introduction of aminoguanidine in influencing renal injury in diabetes [74]. In a 32 week study, diabetic rats were randomised to receive aminoguanidine over the first or last 16 weeks of the study period. It was shown that both treatments were associated with similar effects on renal AGE accumulation, albuminuria and mesangial expression consistent with the hypothesis that the renal injury in diabetes is linked to the time of exposure to increased AGEs.

Since aminoguanidine inhibits AGE formation and also has other actions including inhibition of iNOS [75], we have recently explored the role of a chemically related compound, ALT 946, which has less effect on iNOs [76]. Over the 32 week study period, ALT 946 conferred similar if not superior reno-

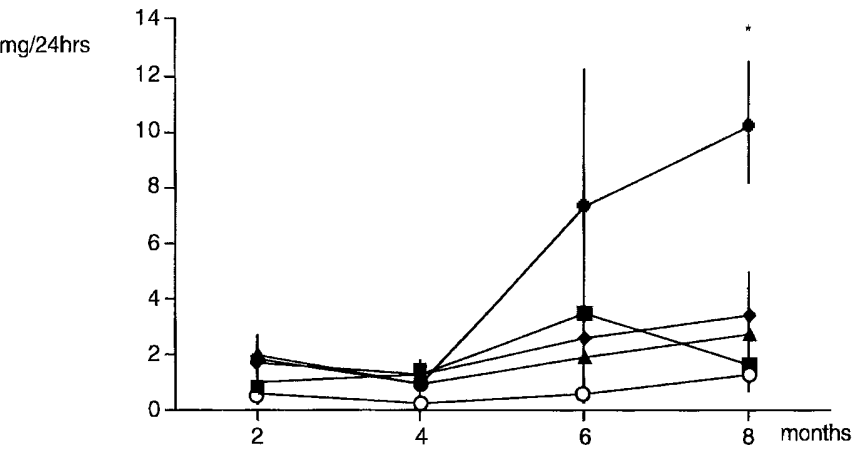

Fig. 2. Serial measurements of albuminuria (y axis) are shown at 8-week intervals for Control ( $\bigcirc)$, Diabetic (O), Diabetic + aminoguanidine $(\diamond)$, Diabetic + ALT-946 (A) and Diabetic + ALT-946 received for only the last 16 weeks of the study (ם). Results are shown as geometric means and tolerance factors. Adapted from [76]

protection to aminoguanidine consistent with the view that the renoprotective effects of aminoguanidine are due to its action as an inhibitor of AGE formation (Fig.2). More recently, an alternative approach to prevent renal AGE accumulation has been developed which involves the use of cross-link breakers which cleave pre-formed AGEs [77]. Although these agents have been shown to have effects on the vasculature in diabetes [78], their specific role in diabetic nephropathy is not well defined.

The mechanisms of action whereby AGEs induce their effects have not been fully elucidated. Firstly, AGEs induce cross-link formation, thereby directly affecting the function of various proteins including the collagens. Secondly, they interact with a range of binding proteins, some of which have been isolated. A number of AGE binding proteins have been identified including receptor for advanced glycation endproducts (RAGE), AGE-R1, AGE-R2, AGE-R3, lactoferrin, lysozyme and the macrophage scavenger receptor [79-82]. Some of these proteins are considered to act as receptors and are involved in the transduction of various effects of AGEs. For example, AGEs interact with the receptor RAGE to stimulate cytokines and to activate NF- $x$ B [83-84]. Other binding proteins such as AGE-R1 could be more important in the clearance of AGEs [85].

The specific role of these receptors in renal injury in diabetes is not yet known. In other diabetic complications such as atherosclerosis it has been postulated that the receptor RAGE could be particularly important with evidence that recombinant soluble RAGE reduces plaque formation in a model of diabetes associated atherosclerosis [86]. Several groups have characterised the distribution of these receptors in the diabetic kidney [87, 88]. RAGE has been shown to be expressed in various renal cell types including the podocyte and tubular epithelial cells [87, 88]. Recently it has been suggested that in the kidney 
RAGE mRNA is expressed in the glomerulus [87] and it is possible that tubular RAGE represents filtered receptor.

In diabetic NOD mice, the expression of the AGE receptors, $\mathrm{R} 1, \mathrm{R} 2$ and $\mathrm{R} 3$ has been characterised [85]. There was a sixfold increase in AGE-R3 with the development of diabetes and a reduced AGE-R1 expression in the prediabetic NOD mice. It is not clear if the abnormality in this receptor, which is implicated in AGE clearance, contributes to delayed AGE removal thereby leading to early renal AGE accumulation and providing an additional mechanism for development of diabetic nephropathy in this model. We investigated the regulation of AGE binding proteins in the diabetic kidney using autoradiographic techniques incubating kidney sections with radiolabelled exogenous AGEs [89]. These experiments confirmed upregulation of AGE binding sites in the diabetic kidney particularly in proximal tubules which was attenuated by aminoguanidine treatment. This would suggest that AGEs could modulate certain AGE binding proteins. The chemical identity of these AGE binding proteins has not been determined but does not seem to be RAGE or any of the other AGE receptors cloned previously.

A major effect of AGEs appears to be the stimulation of various cytokines, including TGF $\beta$, presumably via the receptor dependent pathways which include RAGE. In a recent study, the increased expression of renal TGF $\beta 1$ as well as platelet derived growth factor (PDGF) and the extracellular matrix protein, type IV collagen in the diabetic kidney was attenuated by aminoguanidine in the tubulointersitium [90]. A similar effect has been reported in a model of Type II diabetes, the OLETF rat, by a Japanese group which described reduced TGF $\beta 1$ and vascular endothelial growth factor (VEGF) expression after 68 weeks of treatment with a novel AGE inhibitor, OPB-9195 [91].

Polyols. The accumulation of polyols in the kidney has been suggested to be involved in the development of diabetic nephropathy [92]. Although this pathway has been investigated extensively in terms of neuropathy, more limited exploration of this pathway has been done in renal disease [93]. Renal polyol accumulation has been reported in diabetic nephropathy and inhibition of this phenomenon has been observed with various aldose reductase inhibitors. In the polyol pathway, glucose is reduced to sorbitol by the enzyme aldose reductase. Sorbitol accumulation is associated with depletion of myoinositol and changes in the cellular redox potential [94]. The importance of polyols in activating pathways relevant to diabetic nephropathy has been emphasised with the demonstration that aldose reductase inhibition is associated with reduced protein kinase $\mathrm{C}$ (PKC) activation and TGF $\beta 1$ production in human mesangial cells in response to glucose [95].
In experimental diabetes, several studies have examined the effects of aldose reductase inhibition on various functional and structural markers of diabetic nephropathy [92, 96-98]. The results of various studies are not consistent and could reflect the different animal models, the measurements of renal injury and the aldose reductase inhibitors used. In human diabetic nephropathy, the effects of aldose reductase inhibition have also been conflicting and overall rather disappointing [99]. The major effect appears to be a reduction in hyperfiltration [100] as was observed in some of the experimental studies [100].

Hexosamine pathway. It has been hypothesised that the hexosamine pathway is involved in the development of diabetic complications [101, 102]. In this pathway, glucose is converted to glucose-6-phosphate via hexokinase and subsequently to fructose-6-phosphate as part of the glycolytic pathway. Under control of the rate limiting enzyme glutamine:fructose-6phosphate amidotransferase (GFAT), glucosamine6-phosphate is formed using glutamine as an amino donor. A series of additional reactions then occur, ultimately leading to the generation of other glucosamines which serve as precursors to amino sugars used for the synthesis of proteoglycans, glycolipids and glycoproteins. To explore this pathway investigators have overexpressed the enzyme GFAT [102] or directly inhibited this enzyme. It seems that increased flux through the hexosamine pathway is associated with PKC activation and increased TGF $\beta$ expression [103]. Indeed, glucose induced TGF $\beta$ expression and subsequent matrix production can be inhibited by GFAT blockade using either azaserine or an antisense oligonucleotide approach [101].

Glucose transporters. It has been suggested that glucose transporters, in particular GLUT-1, could play a part in inducing extracellular matrix production in response to hyperglycaemia [104]. The initial studies showed that the effects of glucose on collagen production could be reproduced in mesangial cells overexpressing GLUT-1 despite exposure to normal glucose concentrations [104]. Subsequently it was shown that glucose induces GLUT-1 expression in mesangial cells [105]. Furthermore, this increase in GLUT1 expression leads to increased aldose reductase expression as well as the PKC alpha isoform leading to increased matrix production [106]. To further explore the role of GLUT-1 in mediating expression of matrix proteins such as fibronectin, cells which expressed antisense GLUT-1 were studied [107]. These experiments revealed that glucose did not induce fibronectin expression in the setting of reduced GLUT-1 providing further evidence for this glucose transporter playing an important part in promoting extracellular matrix production. In streptozotocin diabetes various changes in GLUT-1 and other glucose transporters 
have been described in the kidney [108]. The in vivo relevance of this pathway in particular, if GLUT-1 represents another target for the treatment of diabetic complications, has yet to be determined.

Oxidative stress and reactive oxygen species. Oxidative stress is widely recognised by some investigators as a key component in the development of diabetic complications [69]. It is not known, however, if it is an important early link between hyperglycaemia and complications or if it is a consequence of the primary pathogenic mechanisms. A recent study showed that inhibition of reactive oxygen species (ROS) in cultured bovine endothelial cells interferes with multiple independent pathways of hyperglycaemic damage, namely PKC activation, NF- $\varkappa \mathrm{B}$ activation and the formation of advanced glycation end products [109]. Other studies have shown that hyperglycaemia itself could contribute to oxidative events by forming glycation products that can propagate free radicals [69]. The lipid soluble classical anti-oxidant butylated hydroxytoluene (BHT) has been used [110]. These studies showed reductions in renal AGE accumulation and decreases in oxidative stress as measured by TBARS, a relatively crude marker of oxidative stress.

The status of oxidative stress in diabetic nephropathy and other complications is still controversial [111]. Much of the work is in vitro and appears contradictory. In a recent study [109], ROS generation activated AGE dependent pathways in cultured bovine endothelial cells. In contrast, others reported that an AGE/RAGE interaction led to the generation of ROS [83]. Another study also showed that AGEs can induce oxidative stress and activate PKC in neonatal mesangial cells [112]. The link between ROS and PKC also seems to be bi-directional with evidence that ROS generation in certain contexts is PKC dependent [113]. For example, in a study on proximal tubular cells, glucose induced generation of lipid peroxides was attenuated by PKC inhibition [114]. In contrast, ROS have been shown to mediate glucose induced activation of PKC [109] and to generate vasoactive hormones such as endothelin [115] providing another potential site of interaction between haemodynamic and metabolic pathways in diabetic nephropathy. It remains to be determined if oxidative stress is solely an early event in hyperglycaemia-induced vascular injury leading to the activation of other pathways or if oxidative stress is also implicated in downstream critical events for mediating vascular and renal damage. To explore this issue further will require better markers of oxidative stress as well as the use of more specific inhibitors of this pathway.

\section{Intracellular second messengers}

Protein kinase $C(P K C)$. Evidence over the last decade has implicated $\mathrm{PKC}$ as an important mediator of diabetes-induced vascular dysfunction [116]. Initial studies using various cell types, including mesangial cells, indicated that effects of hyperglycaemia on mesangial dysfunction could be mimicked by phorbol esters, direct activators of PKC, and could be attenuated by non-specific PKC inhibitors [117]. Further studies identified that certain isoforms of this intracellular second messenger were preferentially activated in the diabetic kidney [118] and therefore these isoforms were considered as targets for development of inhibitors. A specific $\mathrm{PKC} \beta$ inhibitor, LY333531, was developed and in streptozotocin diabetic rats treated with this agent for over 12 weeks was shown to attenuate glomerular hyperfiltration, reduce albuminuria and decrease expression of TGF $\beta$ and various extracellular matrix proteins $[118,119]$. More recently, this PKC inhibitor was administered to $d b / d b$ mice, a model of Type II diabetes, for 16 weeks [120]. In addition to normalising glomerular PKC activity, urinary albumin excretion was reduced as was TGF $\beta 1$, fibronectin and type IV collagen expression. These recent findings confirm the potential utility of this class of agents in diabetic nephropathy.

Investigators have explored the effects of other treatments on renal PKC activation [121]. Of note, both the ACE inhibitor, ramipril, and the inhibitor of AGE formation, aminoguanidine, were associated with prevention of diabetes associated increases in PKC activation. Furthermore, the effects of these agents on PKC activity were also observed at other sites of vascular injury including the retina and mesenteric vascular bed [122]. These findings suggest that AGEs and AII could activate PKC in vivo. Furthermore, it is possible that $\mathrm{PKC}$ represents a critical downstream event in the pathogenesis of diabetic nephropathy. Indeed, various actions of cytokines implicated in diabetic complications such as VEGF are PKC dependent [123]. In addition, PKC modulates the effects of glucose including VEGF and TGF $\beta$ expression $[124,125]$.

Nuclear factor kappa $B(N F-\varkappa B)$. NF- $\varkappa \mathrm{B}$ is a transcription factor composed of two subunits, the most common of which are the p50 and p65 subunits [126]. NF- $x \mathrm{~B}$ is ubiquitously expressed and is stored in an inactive form bound to inhibitors in the cytoplasm. P50 is usually complexed with the p65 subunit and thus has the ability to activate numerous genes including cytokines, adhesion molecules, nitric oxide synthase, angiotensinogen and many other inflammatory and proliferative proteins implicated in the process of diabetic nephropathy [126]. NF- $x \mathrm{~B}$ is activated by a range of stimuli including glucose [127]. This 
Table 1. Stimuli and inhibitors of TGF $\beta$ expression

\begin{tabular}{lll}
\hline Stimuli & Inhibitors & Reference \\
\hline Glucose & Insulin & {$[142]$} \\
Stretch & ?Antihypertensive agents & {$[144]$} \\
AII & $\begin{array}{l}\text { ACE inhibition/AT1 recep- } \\
\text { tor blockade }\end{array}$ & {$[29,158]$} \\
& Aminoguanidine & {$[90,143]$} \\
AGEs & PKC $\beta_{2}$ & {$[118,120]$} \\
PKC & ?Anti-oxidants & {$[148]$} \\
Isoprostanes & HMG CoA reductase & {$[147]$} \\
?Lipids & inhibitors & \\
Glycosaminoglycans & Heparin & {$[155]$} \\
Hexosamines (e.g. glu- & ?GFAT inhibitors & {$[101]$} \\
cosamine-6-phosphate) & & \\
TGF $\beta$ (autocrine) & TGF $\beta$ neutralising anti- & {$[141]$} \\
Endothelin & bodies/Decorin & \\
Thrombospondin-1 & ?Endothelin antagonists & {$[146]$} \\
\hline
\end{tabular}

GFAT, glutamine: fructose-6-phosphate amidotransferase; HMG CoA reductase, Hydroxy methyl glutaryl CoA reductase

phenomenon seems to be PKC dependent [127] and can be prevented by antioxidants [123]. AGEs are also involved in activation of $\mathrm{NF}-\varkappa \mathrm{B}$ via a RAGE-dependent pathway leading to its translocation to the nucleus where it induces transcription [83]. The promoter region of the RAGE gene also contains NF$x \mathrm{~B}$ binding sites [128]. This provides a pathway for perpetuation of injury not only because NF- $x \mathrm{~B}$ is activated in response to RAGE, but RAGE is also activated by NF- $\varkappa$ B. This is supported by studies in which mutations of both NF- $\varkappa \mathrm{B}$ like binding sites in the promoter region of RAGE led to stimulated promoter expression [128].

The NF- $\varkappa$ B inhibitor, pyrollidine dithiocarbamate (PDTC) has been studied in non-diabetic models of fibrosis and shown to confer renoprotection [124]. However, approaches to inhibit NF- $x \mathrm{~B}$ have not been explored in diabetic nephropathy. The diverse actions of NF- $x \mathrm{~B}$ and the capacity of various factors such as AII and AGEs to activate this transcription factor $[31,83]$ are consistent with $\mathrm{NF}-x \mathrm{~B}$ playing a pivotal role in modulating diabetic complications. It is possible that $\mathrm{NF}-\varkappa \mathrm{B}$ like $\mathrm{PKC}$ represents a major site of interaction between haemodynamic and glucose dependent pathways in the development of diabetic vascular complications.

MAP kinase. Mitogen-activated protein kinase (MAPK) is a major signalling system which transduces extracellular signals to intracellular responses [130]. Three major subgroups have been identified, the extracellular signal regulated kinase (ERK) family, C-Jun N-terminal kinase (JNK)/stress-activated protein kinase (SAPK), and p38 MAPK. The MAPK cascades play a central part in a range of biological processes relevant to diabetic nephropathy including cell growth, differentiation and apoptosis [131]. Glucose has been reported to activate MAPKs including p38 MAPK [132]. This increase in MAPK has also been noted in glomeruli from diabetic rats [133, 134], and the increase in MAPK in response to hyperglycaemia has been shown to be PKC dependent [134]. Recently it has been hypothesised that MAPK could play a central role in the pathogenesis of diabetic complications [130]. Various stimuli in addition to glucose activate these enzymes including AGEs [135], polyols [136] and PKC [134]. The activation of the angiotensinogen gene by glucose also appears to be p38 dependent [137]. The exact role of this family of kinases is not clear but, of relevance to diabetic nephropathy, MAPK was found to play an important role in the TGF $\beta$ signalling pathway [131] and in mediating the prosclerotic effect of this cytokine [138].

\section{Cytokines}

Transforming growth factor $\beta$ (TGF $\beta$ ). Transforming growth factor betas are part of a superfamily with three mammalian isoforms. The major isoform, TGF $\beta 1$ is synthesised as an inactive or latent form which is subject to proteolytic cleavage leading to the generation of the active form. TGF $\beta$ binds to the type II receptor and subsequently binds to the type I receptor which is then phosphorylated to induce intracellular signalling involving the Smad proteins [139]. These actions of TGF $\beta$ via the Smad pathway are modulated by a range of signalling pathways including NF- $x \mathrm{~B}$ and MAPK [140].

TGF $\beta 1$ is considered the pivotal cytokine in mediating collagen formation in the kidney [141]. Not only does it stimulate gene expression of various matrix proteins but it influences the matrix degrading enzyme pathways by inhibiting the synthesis of matrix metalloproteinases and stimulating the production of metalloproteinase inhibitors (TIMPs) [141]. In vitro studies have shown that a range of stimuli increase TGF $\beta$ expression (Table 1). These include hyperglycaemia, AGEs, stretch, AII, endothelin, lipids and various products of oxidative stress such as $\mathrm{F}_{2}$ isoprostanes, all factors relevant to the progression of diabetic nephropathy [142-148]. Induction of TGF $\beta 1$ by glucose and glycated proteins seems to be a PKCdependent phenomenon [149]. A recent study has suggested that glucose-induced effects in increasing conversion of latent TGF $\beta$ to the active form could involve thrombospondin-1 in mesangial cellls [150]. A range of novel proteins has been identified which is stimulated by TGF $\beta 1$ and increased in the diabetic kidney [151, 152]. These include gremlin, an antagonist of bone morphogenic proteins [151] and LSGK, a serine and threonine kinase, implicated in renal tu- 
bular sodium transport [152]. Indeed, TGF $\beta$ seems to be an important site of interaction between haemodynamic and metabolic pathways, playing a pivotal role in the synergy between hypertension and hyperglycaemia in mediating diabetic nephropathy. It is likely that this multi-functional cytokine has a range of direct as well as indirect effects which mediate many of the functional and structural features of diabetic nephropathy. Therefore it is a prime candidate for developing appropriate antagonists in the prevention and treatment of diabetic nephropathy.

In experimental and human diabetic nephropathy, TGF $\beta 1$ expression is increased [153]. Because TGF $\beta 1$ is synthesised as a latent peptide, it cannot be assumed that gene or protein expression is a marker of increased TGF $\beta 1$ activity. Our group evaluated the expression of a matrix protein which is selectively induced by TGF $\beta$, a $\beta$-inducible gene $\mathrm{H} 3$ [154]. This protein is expressed in the kidney and there is evidence of upregulation in the diabetic kidney consistent with increased TGF $\beta$ bioactivity in this context [154]. Further evidence of a functional role for TGF $\beta$ in mediating various structural hallmarks of diabetic nephropathy such as glomerular hypertrophy and glomerulosclerosis has been obtained from studies using neutralising antibodies in diabetic mice [9]. Administration of TGF $\beta$ antibodies to these mice led to improvement in renal function and reduced extracellular matrix accumulation. Proteinuria was not affected suggesting that this functional marker of diabetic nephropathy might not be TGF $\beta$-dependent and that the pathogenesis of albuminuria and glomerular structural injury in diabetic nephropathy is not necessarily identical.

Various therapeutic approaches which confer renoprotection as outlined previously such as agents which interrupt the renin-angiotensin system, inhibitors of advanced glycation, hydroxymethylglutaryl (HMG)CoA reductase inhibitors, heparin and inhibitors of specific PKC isoforms are associated with reduced renal TGF $\beta 1$ expression in the context of less glomerular and tubulointerstitial injury [29, 90, 120, $147,155]$. Although most studies have focussed on $\mathrm{TGF} \beta 1$, the status of the other $\mathrm{TGF} \beta$ isoforms as well as the TGF $\beta$ receptors in experimental diabetes has also been evaluated $[156,157]$. There is upregulation of TGF $\beta 2$, TGF $\beta 3$ and the TGF $\beta$ RII receptors in the diabetic kidney. Each protein appears to have its own spatial and possibly temporal distribution within the diabetic kidney with changes observed in the glomerulus and also in the tubulointerstitium. Furthermore, the various TGF $\beta$ receptors seem to be reduced by renoprotective treatments such as ACE inhibitors [158]. This effect on TGF $\beta$ receptors could represent a major mechanism of action of agents which interrupt the RAS.

Although the TGF $\beta$ family and specifically TGF $\beta 1$ is considered the major prosclerotic cytokine implicated in the progression of renal disease; other cyto- kines, some of which are generally considered to be primarily proliferative such as PDGF [159] could also act in a prosclerotic manner. Increases in PDGF gene expression have been reported in the diabetic kidney $[90,160]$. Investigation of the role of PDGF per se in progressive renal injury has been assisted by the development of PDGF receptor antagonists [161]. Such a compound, STI-571, a tyrosine kinase inhibitor has been shown to confer a degree of protection in a model of renal injury which is considered to be partly PDGF-dependent, the anti Thy1 model of glomerulonephritis [162]. Whether this class of compound also confers renal protection in diabetes has yet to be determined.

Another prosclerotic cytokine, connective tissue growth factor (CTGF) has been shown to have increased renal and glomerular expression in diabetes [163]. The synthesis of this peptide is stimulated by TGF $\beta$, hyperglycaemia or cyclic mechanical stretch [163], with all these stimuli relevant to the pathogenesis of diabetic nephropathy. Furthermore, CTGF could induce its own expression providing a potential mechanism for inducing a perpetual cycle of progressive renal injury. The induction of CTGF by hyperglycaemia seems to be partly TGF $\beta$-dependent. The importance of this growth factor in diabetic nephropathy and its relation to TGF $\beta$ expression has not been fully characterised. Of interest, AGEs have recently been reported to increase CTGF expression, albeit not in a renal context [164].

Vascular endothelial growth factor (VEGF). Vascular endothelial growth factor (VEGF) is a cytokine whose major role in diabetes has been considered to be in the pathogenesis of diabetic retinopathy and in particular retinal neovascularisation [165]. VEGF is highly expressed in the kidney, primarily in the glomerular podocytes but also in distal tubules and collecting ducts [166]. Its major receptor, VEGF-R2 is also expressed in the kidney, primarily on endothelial cells but also on cortical interstitial fibroblasts. Our group has explored gene and protein expression of VEGF and its receptor VEGF-R2, in the diabetic kidney [166]. To further address the status of VEGF receptors in the diabetic kidney, we have utilised in vitro and in vivo autoradiographic techniques using radiolabelled VEGF. VEGF expression is increased in the diabetic kidney. Renal VEGF receptor-2 expression seems to be increased early in experimental diabetes but this increase is not sustained after 32 weeks of diabetes. A similar pattern was observed when assessing VEGF binding sites in the kidney using autoradiographic techniques (Fig. 3). The functional significance of these changes in VEGF and its receptor in the diabetic kidney is not known. It is not certain if the VEGF pathway is implicated in the development of albuminuria in diabetes or if renal angiogenesis is an important phenomenon in the diabetic kidney. Of 

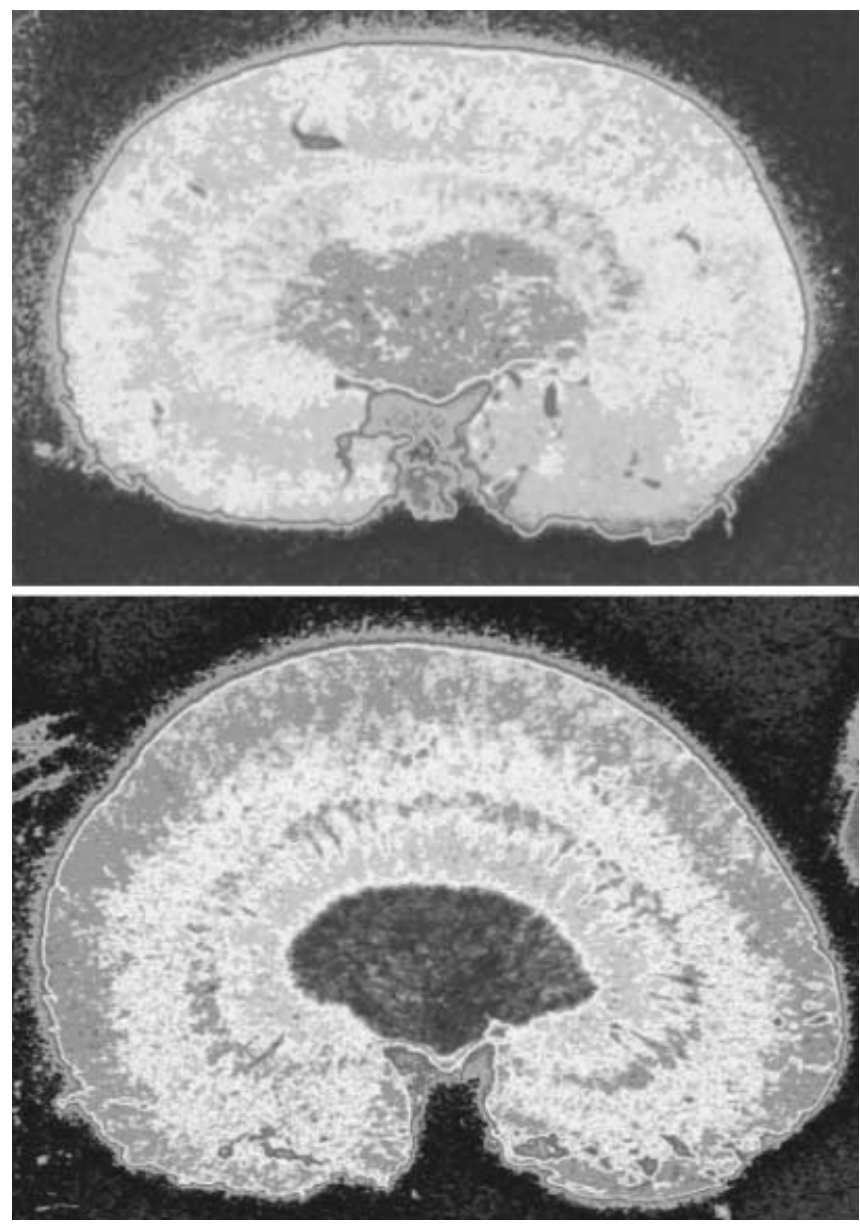

Fig. 3. ${ }^{125} \mathrm{I}-\mathrm{VEGF}$ binding in a control kidney (upper panel) and in a kidney from a rat with 3 weeks of streptozotocin diabetes (lower panel) rats is indicated semiquantitatively in pseudocolorized computer images (blue-nil, green-low, yellow-moderate, red-high). Adapted from [166]

interest, administration of neutralising antibody to VEGF for 6 weeks was associated with resolution of hyperfiltration and attenuation of albuminuria [167].

A range of stimuli for VEGF expression and/or signalling have been identified which could be relevant to diabetic nephropathy. These include hyperglycaemia, AGEs, PKC, mechanical stretch and AII [168-171]. Our studies in the retina suggest that ACE inhibitors reduce retinal VEGF expression in diabetic and non-diabetic models of retinal disease in association with a decrease in retinal albumin permeability and neovascularisation $[172,173]$. In experimental diabetic nephropathy, VEGF expression is decreased by an inhibitor of AGE formation [91].

A range of other cytokines have also been implicated in diabetic nephropathy. Epidermal growth factor (EGF) has been reported to be increased in the diabetic kidney [174]. However, the pathophysiological relevance of this finding needs to be ascertained. A large body of evidence now exists for various changes in the Growth Hormone-IGF pathway in the dia- betic kidney [175-177] as well as data indicating that inhibition of this pathway by various approaches influences renal ultrastructural injury as reviewed recently [4].

\section{Nephrin}

A major determinant of proteinuria seems to be the glomerular slit diaphragm. Recent advances in the nature and molecular properties of the slit diaphragm have included the identification of the protein, nephrin which is a transmembrane protein of the Ig superfamily that acts as an adhesion receptor and signalling protein $[178,179]$. Our group recently observed a deficiency in glomerular nephrin in SHR after 32 weeks of diabetes [180] (Fig.4). A similar deficiency in nephrin has been reported in other models of renal disease including Passive Heymann nephritis [181] as well as in acquired human nephrotic syndrome [182]. In our studies, administration of the AII antagonist, irbesartan, to diabetic SHR restored the reduced nephrin content in the diabetic kidney [180]. These changes occurred in association with attenuation of albuminuria. Similar preservation of glomerular nephrin content has been noted by investigators in another model of renal disease using both ACE inhibitors and AII antagonists in association with the prevention of proteinuria and renal injury [181]. These investigators suggested that the renoprotection afforded by agents which block the RAS could involve effects on nephrin assembly. However, it is not certain if the changes in nephrin are causative or secondary to renal disease. Over the last few years other slit diaphragm proteins have been isolated and it is anticipated that this aspect of renal research will be a major area of ongoing investigation [183].

\section{Outlook}

The experimental studies described above have provided insights into the mechanisms responsible for diabetic nephropathy and led to the development of appropriate clinical trials. Blockade of the RAS has been investigated extensively and is now considered a first line treatment for diabetic nephropathy by many international organizations [184]. The Action 1 trial evaluating aminoguanidine in diabetic nephropathy was instituted, based on preclinical findings of this agent. Preliminary findings from that study suggest beneficial effects on proteinuria and a trend towards preservation of renal function, although this did not reach statistical significance (www.Alteon Pharma/pimag1.htm.com). It is anticipated that over the next few years more novel agents such as PKC inhibitors and vasopeptidase inhibitors will be investigated in clinical trials. Nevertheless, despite a range 


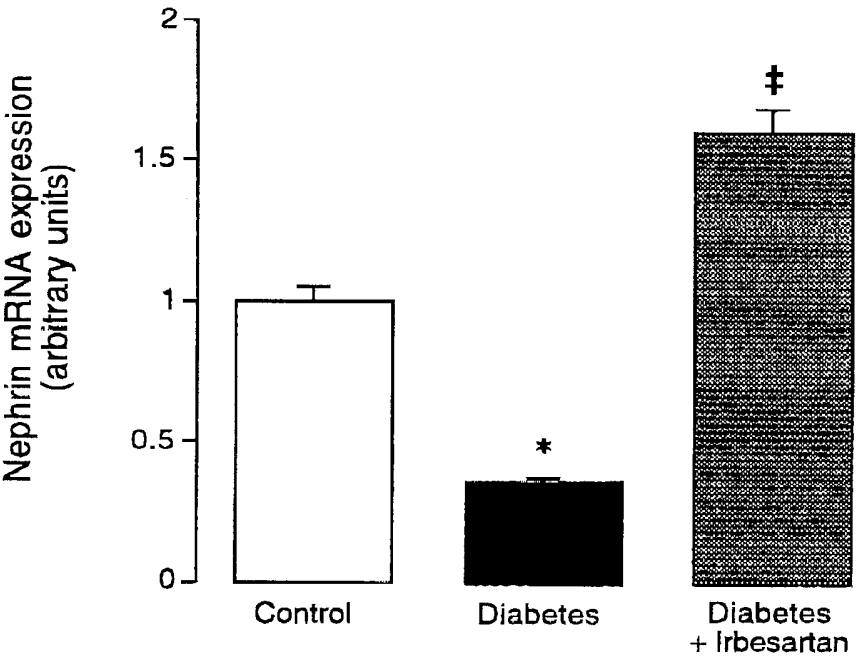

Fig. 4. Measurement of renal nephrin gene expression by RTPCR in control SHR, diabetic SHR and diabetic SHR treated for 32 weeks with the AII antagonist, irbesartan. Adapted from [180]

of new treatments for diabetic nephropathy, the mainstay of therapy involving optimisation of glycaemic control and aggressive antihypertensive therapy remains the best approach to retard the progression of diabetic nephropathy [36].

As further studies identify important sites of interaction between these metabolic and haemodynamic pathways and pivotal downstream events, it will be possible to develop a more targeted approach for the prevention and treatment of diabetic nephropathy. This will be greatly facilitated by the development of improved models of diabetic nephropathy and newer approaches such as microarray technology [185] and proteomics which will assist in identifying novel targets for ongoing research and development, as part of a rational strategy for the management of diabetic nephropathy.

Sources. The review is based on the relevant literature published in the English language during the period 1990-2001, and seminal prior contributions. The sources available to the authors were intergrated with sources identified through PubMed searches for "kidney and diabetes".

Acknowledgements. This work was supported by centre and individual project grants from the Juvenile Diabetes Foundation International, National and Central Health Medical Research Councils of Australia, Australian Kidney Foundation and Austin Hospital Medical Research Foundation. The author wishes to thank Dr Jerums for helpful discussions and L. Ring for excellent editorial assistance.

\section{References}

1. Adler AI, Stratton IM, Neil HAW et al. (2000) Association of systolic blood pressure with macrovascular and microvascular complications of type 2 diabetes (UKPDS 36): prospective observational study. BMJ 321: 412-419

2. Stratton IM, Adler AI, Neil HAW et al. (2000) Association of glycaemia with macrovascular and microvascular complications of type 2 diabetes (UKPDS 35): prospective observational study. BMJ 321: 405-412

3. Cooper ME, Gilbert RE and Epstein M (1998) Pathophysiology of diabetic nephropathy. Metabolism 47 [Suppl 1]: 3-6

4. Flyvbjerg A (2000) Putative pathophysiological role of growth factors and cytokines in experimental diabetic kidney disease [Review]. Diabetologia 43: 1205-1223

5. Kelly DJ, Allen TJ, Cooper ME (2000) Experimental diabetic nephropathy: Is it relevant to the human disease. Nephrology 5: 177-185

6. Kasiske BL, O'Donnell MP, Cleary MP, Keane WF (1988) Treatment of hyperlipidemia reduces glomerular injury in obese Zucker rats (OZ). Kidney Inter 33: 667-672

7. Velasquez MT, Kimmel PL, Michaelis OEIV (1990) Animal models of spontaneous diabetic kidney disease. FASEB J 4: 2850-2859

8. Kelly DJ, Wilkinson-Berka JL, Allen TJ, Cooper ME, Skinner SL (1998) A New Model of Diabetic Nephropathy with Progressive Renal Impairment in the Transgenic (mRen-2)27 Rat (Tgr). Kidney Int 54: 343-352

9. Ziyadeh FN, Hoffman BB, Han DC et al. (2000) Longterm prevention of renal insufficiency, excess matrix gene expression, and glomerular mesangial matrix expansion by treatment with monoclonal antitransforming growth factor-beta antibody in $\mathrm{db} / \mathrm{db}$ diabetic mice. Proc Natl Acad Sci USA 97: 8015-8020

10. Cooper ME, Allen TJ, O'Brien R, Clarke B, Jerums G, Doyle AE (1988) Effects of genetic hypertension on diabetic nephropathy in the rat - functional and structural characteristics. J Hypertens 6: 1009-1016

11. Cooper ME, Allen TJ, O'Brien RC et al. (1990) Nephropathy in model combining genetic hypertension with experimental diabetes. Enalapril versus hydralazine and metoprolol therapy. Diabetes 39: 1575-1579

12. Zatz R, Dunn BR, Meyer TW, Brenner B (1986) Prevention of diabetic glomerulopathy by pharmacological amelioration of glomerular capillary hypertension. J Clin Invest 77: 1925-1930

13. Hostetter T, Rennke H, Brenner B (1982) The case for intrarenal hypertension in the initiation and progression of diabetic and other glomerulopathies. Am J Med 72: 375-380

14. Zatz R, Meyer TW, Rennke HG, Brenner BM (1985) Predominance of hemodynamic rather than metabolic factors in the pathogenesis of diabetic glomerulopathy. Proc Natl Acad Sci USA 82: 5963-5967

15. Mullins JJ, Peters J, Ganten D (1990) Fulminant hypertension in transgenic rats harbouring the mouse Ren-2 gene. Nature 344: 541-544

16. Kelly DJ, Skinner SL, Gilbert RE, Cox AJ, Cooper ME, Wilkinson-Berka JL (2000) Effects of endothelin or angiotensin II receptor blockade on diabetes in the transgenic (mRen-2)27 rat. Kidney Int 57: 1882-1894

17. Leehey DJ, Singh AK, Alavi N, Singh R (2000) Role of angiotensin II in diabetic nephropathy. Kidney Int 58: S93-S98

18. Anderson S, Jung FF, Ingelfinger JR (1993) Renal reninangiotensin system in diabetes: functional, immunohisto- 
chemical, and molecular biological correlations. Am J Physiol 265: F477-F486

19. Kalinyak JE, Sechi LA, Griffin CA et al. (1993) The renin-angiotensin system in streptozotocin-induced diabetes mellitus in the rat. J Am Soc Nephrol 4: 1337-1345

20. Campbell DJ, Kelly DJ, Wilkinson-Berka JL, Cooper ME, Skinner SL (1999) Increased bradykinin and 'normal' angiotensin peptide levels in streptozotocin-diabetic Sprague Dawley and TGR(mRen-2) rats. Kidney Inter 56: 211-221

21. Zhang SL, Filep JG, Hohman TC, Tang SS, Ingelfinger JR, Chan JSD (1999) Molecular mechanisms of glucose action on angiotensinogen gene expression in rat proximal tubular cells. Kidney Int 55: 454-464

22. Singh R, Alavi N, Singh AK, Leehey DJ (1999) Role of angiotensin II in glucose-induced inhibition of mesangial matrix degradation. Diabetes 48: 2066-2073

23. Gilbert RE, Wu LL, Kelly DJ et al. (1999) Pathological expression of renin and angiotensin II in the renal tubule after subtotal nephrectomy - implications for the pathogenesis of tubulointerstitial fibrosis. Am J Pathol 155: 429-440

24. Zimpelmann J, Kumar D, Levine DZ et al. (2000) Early diabetes mellitus stimulates proximal tubule renin mRNA expression in the rat. Kidney Int 58: 2320-2330

25. Burns KD (2000) Angiotensin II and its receptors in the diabetic kidney [Review]. Am J Kidney Dis 36: 449-467

26. Wolf G, Ziyadeh FN (1997) The role of angiotensin II in diabetic nephropathy: emphasis on nonhemodynamic mechanisms. Am J Kidney Dis 29: 153-163

27. Kagami S, Border WA, Miller DE, Noble NA (1994) Angiotensin II stimulates extracellular matrix protein synthesis through induction of transforming growth factorbeta expression in rat glomerular mesangial cells. J Clin Invest 93: 2431-2437

28. Wu L, Cox A, Roe C, Dziadek M, Cooper ME, Gilbert RE (1997) Transforming growth factor $B 1$ and renal injury following subtotal nephrectomy in the rat: Role of the renin-angiotensin system. Kidney Int 51: 1553-1567

29. Gilbert RE, Cox A, Wu LL et al. (1998) Expression of transforming growth factor- $\beta 1$ and type IV collagen in the renal tubulointerstitium in experimental diabetes: effects of angiotensin converting enzyme inhibition. Diabetes 47: 414-422

30. Nagahama T, Hayashi K, Ozawa Y, Takenaka T, Saruta T (2000) Role of protein kinase C in angiotensin II-induced constriction of renal microvessels. Kidney Int 57: 215-223

31. Ruiz-Ortega M, Lorenzo O, Ruperez M, Konig S, Wittig B, Egido J (2000) Angiotensin II activates nuclear transcription factor kappa B through AT(1) and AT(2) in vascular smooth muscle cells - Molecular mechanisms. Circ Res 86: 1266-1272

32. Shankland SJ, Wolf G (2000) Cell cycle regulatory proteins in renal disease: role in hypertrophy, proliferation, and apoptosis [Review]. Am J Physiol - Renal Physiol 278: F515-F529

33. Bonnet F, Cao Z, Cooper M (2001) Apoptosis and angiotensin II; yet another renal regulatory system. Exp Nephrol 9: 295-300

34. Allen TJ, Cao Z, Youssef S, Hulthen UL, Cooper ME (1997) The role of angiotensin II and bradykinin in experimental diabetic nephropathy: functional and structural studies. Diabetes 46: 1612-1618

35. Wolf G (2000) Cell cycle regulation in diabetic nephropathy. Kidney Int 58: S59-S66

36. Cooper ME (1998) Pathogenesis, prevention and treatment of diabetic nephropathy. Lancet 352: 213-219
37. Cao ZM, Kelly DJ, Cox A et al. (2000) Angiotensin type 2 receptor is expressed in the adult rat kidney and promotes cellular proliferation and apoptosis. Kidney Int 58: 2437-2451

38. Remuzzi A, Perico N, Amuchastegui CS et al. (1993) Short- and long-term effect of angiotensin II receptor blockade in rats with experimental diabetes. J Am Soc Nephrol 4: 40-49

39. Andersen S, Tarnow L, Rossing P, Hansen BV, Parving $\mathrm{HH}$ (2000) Renoprotective effects of angiotensin II receptor blockade in type 1 diabetic patients with diabetic nephropathy. Kidney Int 57: 601-606

40. Lacourciere Y, Belanger A, Godin C et al. (2000) Longterm comparison of losartan and enalapril on kidney function in hypertensive type 2 diabetics with early nephropathy. Kidney Int 58: 762-769

41. Lewis EJ, Hunsicker LG, Bain RP, Rohde RD (1993) The effect of angiotensin converting enzyme inhibition on diabetic nephropathy. N Engl J Med 329: 1456-1462

42. Mogensen CE, Neldam S, Tikkanen I et al. (2000) Randomised controlled trial of dual blockade of renin-angiotensin system in patients with hypertension, microalbuminuria, and non-insulin dependent diabetes: the candesartan and Lisinopril microalbuminuria (CALM) study. BMJ 321: 1440-1444

43. Cao Z, Bonnet F, Davis B, Cox AJ, Allen T, Cooper ME (2001) Additive hypotensive and antialbuminuric effects of angiotensin converting enzyme inhibition and angiotensin receptor antagonism in diabetic spontaneously hypertensive rat. Cl Sci (Colch) 100: 591-599

44. Wilkinson-Berka JL, Gibbs N, Skinner SL, Cooper ME, Kelly DJ (2001) Renoprotective and anti-hypertensive effects of combined valsartan and perindopril in progressive diabetic nephropathy in the transgenic (mRen2)27 rat. Nephrology, Dialysis, Transplantation 16: 1343-1349

45. Johnston CI, Risvanis J, Naitoh M, Tikkanen I (1998) Mechanism of progression of renal disease - current hemodynamic concepts. J Hypertens 16: S3-S7

46. Benigni A, Remuzzi G (1999) Endothelin antagonists. Lancet 353: 133-138

47. Burrell LM, Risvanis J, Johnston CI, Naitoh M, Balding LC (2000) Vasopressin receptor antagonism - a therapeutic option in heart failure and hypertension. Exp Physiol 85: 259S-265S

48. Johnston CI, Naitoh M, Risvanis J, Farina N, Burrell LM (1998) New hormonal blockade strategies in cardiovascular disease. Scand Cardiovasc J 32: 61-66

49. Burrell LM, Droogh J, in't Veld OM, Rockell MD, Farina NK and Johnston CI (2000) Antihypertensive and antihypertrophic effects of omapatrilat in SHR. Am J Hypertens 13: $1110-1116$

50. Cao Z, Burrell LM, Tikkanen I, Bonnet F, Cooper ME, Gilbert R (2001) Vasopeptidase inhibition attenuates the progression of renal injury in subtotal nephrectomised rats. Kidney Int 60: 715-721

51. Tikkanen T, Tikkanen I, Rockell MD et al. (1998) Dual inhibition of neutral endopeptidase and angiotensin-converting enzyme in rats with hypertension and diabetes mellitus. Hypertension 32: 778-785

52. Hargrove GM, Dufresne J, Whiteside C, Muruve DA, Wong NCW (2000) Diabetes mellitus increases endothelin-1 gene transcription in rat kidney. Kidney Int 58: $1534-1545$

53. Fukui M, Nakamura T, Ebihara I et al. (1993) Gene expression for endothelins and their receptors in glomeruli of diabetic rats. J Lab Clin Med 122: 149-156 
54. Cao ZM, Cooper ME, Wu LL et al. (2000) Blockade of the renin-angiotensin and endothelin systems on progressive renal injury. Hypertension 36: 561-568

55. Benigni A, Colosio W, Brena C, Bruzzi I, Bertani T, Remuzzi G (1998) Unselective inhibition of endothelin receptors reduces renal Dysfunction in experimental diabetes. Diabetes 47: 450-456

56. Jandeleit-Dahm K, Allen TJ, Youssef S, Gilbert RE, Cooper ME (2000) Is there a role for endothelin antagonists in diabetic renal disease? Diabetes Obes Metab 2: 15-24

57. Bank N, Aynedjian HS (1993) Role of EDRF (nitric oxide) in diabetic renal hyperfiltration. Kidney Int 43: 1306-1312

58. Pieper GM (1999) Enhanced, unaltered and impaired nitric oxide-mediated endothelium-dependent relaxation in experimental diabetes mellitus: importance of disease duration. Diabetologia 42: 204-213

59. Komers R, Allen TJ, Cooper ME (1994) Role of endothelium-derived nitric oxide in the pathogenesis of the renal hemodynamic changes of experimental diabetes. Diabetes 43: 1190-1197

60. Tolins JP, Shultz PJ, Raij L, Brown DM, Mauer SM (1993) Abnormal renal hemodynamic response to reduced renal perfusion pressure in diabetic rats: role of NO. Am J Physiol 265: F886-F895

61. Veelken R, Hilgers KF, Hartner A, Haas A, Bohmer KP, Sterzel RB (2000) Nitric oxide synthase isoforms and glomerular hyperfiltration in early diabetic nephropathy. J Am Soc Nephrol 11: 71-79

62. Sugimoto H, Shikata K, Matsuda M et al. (1998) Increased expression of endothelial cell nitric oxide synthase (ecNOS) in afferent and glomerular endothelial cells is involved in glomerular hyperfiltration of diabetic nephropathy. Diabetologia 41: 1426-1434

63. Soulis T, Cooper ME, Sastra S et al. (1997) Relative Contributions of Advanced Glycation and Nitric Oxide Synthase Inhibition to Aminoguanidine-Mediated Renoprotection in Diabetic Rats. Diabetologia 40: 1141-1151

64. Schwartz D, Schwartz IF, Blantz RC (2001) An analysis of renal nitric oxide contribution to hyperfiltration in diabetic rats. J Lab Clin Med 137: 107-114

65. Yagihashi N, Nishida N, Seo HG, Taniguchi N, Yagihashi S (1996) Expression of nitric oxide synthase in macula densa in streptozotocin diabetic rats. Diabetologia 39: 793-799

66. Keynan S, Hirshberg B, Levin-Iaina N et al. (2000) Renal nitric oxide production during the early phase of experimental diabetes mellitus. Kidney Int 58: 740-747

67. Thuraisingham RC, Nott CA, Dodd SM, Yaqoob MM (2000) Increased nitrotyrosine staining in kidneys from patients with diabetic nephropathy. Kidney Int 57: 1968-1972

68. Brownlee M (1994) Lilly Lecture 1993. Glycation and diabetic complications. Diabetes 43: 836-841

69. Baynes JW, Thorpe SR (1999) Role of oxidative stress in diabetic complications: a new perspective on an old paradigm. Diabetes 48: 1-9

70. Wells-Knecht KJ, Brinkmann E, Wells-Knecht MC et al. (1996) New biomarkers of Maillard reaction damage to proteins. Nephrol Dial Transplantation 11 [Suppl 5]: $41-47$

71. Sell DR, Nagaraj RH, Grandhee SK et al. (1991) Pentosidine: a molecular marker for the cumulative damage to proteins in diabetes, aging, and uremia. Diabetes Metab Rev 7: 239-251

72. Soulis-Liparota T, Cooper M, Papazoglou D, Clarke B, Jerums G (1991) Retardation by aminoguanidine of de- velopment of albuminuria, mesangial expansion, and tissue fluorescence in streptozocin-induced diabetic rat. Diabetes 40: 1328-1334

73. Nicholls K, Mandel T (1989) Advanced glycosylation end products in experimental murine diabetic nephropathy: effect of islet grafting and of aminoguanidine. Lab Invest 60: $486-489$

74. Soulis T, Cooper ME, Vranes D, Bucala R, Jerums G (1996) The effects of aminoguanidine in preventing experimental diabetic nephropathy are related to duration of treatment. Kidney Int 50: 627-634

75. Corbett JA, Tilton RG, Chang K et al. (1992) Aminoguanidine, a novel inhibitor of nitric oxide formation, prevents diabetic vascular dysfunction. Diabetes 41: 552-556

76. Forbes JM, Soulis T, Thallas V et al. (2001) Renoprotective effects of a novel inhibitor of advanced glycation. Diabetologia 44: 108-114

77. Vasan S, Zhang X, Zhang X et al. (1996) An agent cleaving glucose-derived protein crosslinks in vitro and in vivo. Nature 382: 275-278

78. Wolffenbuttel BHR, Boulanger CM, Crijns FRL et al. (1998) Breakers of advanced glycation end products restore large artery properties in experimental diabetes. Proc Natl Acad Sci USA 95: 4630-4634

79. Neeper M, Schmidt A, Brett J et al. (1992) Cloning and expression of a cell surface receptor for advanced glycation end products of proteins. J Biol Chem 267: 14998-15004

80. Li Y, Mitsuhashi T, Wojciechowicz D et al. (1996) Molecular identity and distribution of advanced glycation endproducts receptors: relationship of p60 to OST-48 and p90 to 80K-H membrane proteins. Proc Natl Acad Sci USA 93: 11047-11052

81. Li YM, Tan AX, Vlassara H (1995) Antibacterial activity of lysozyme and lactoferrin is inhibited by binding of advanced glycation-modified proteins to a conserved motif. Nat Med 1: 1057-1061

82. Araki N, Higashi T, Mori Tet al. (1995) Macrophage scavenger receptor mediates the endocytic uptake and degradation of advanced glycation end products of the Maillard reaction. Eur J Biochem 230: 408-415

83. Yan SD, Schmidt AM, Anderson GM et al. (1994) Enhanced cellular oxidantstress by the interaction of advanced glycation end products with their receptors binding proteins. J Biol Chem 269: 9889-9897

84. Kislinger T, Fu CF, Huber B et al. (1999) N-epsilon-(carboxymethyl)lysine adducts of proteins are ligands for receptor for advanced glycation end products that activate cell signaling pathways and modulate gene expression. J Biol Chem 274: 31740-31749

85. He CJ, Zheng F, Stitt S, Striker L, Hattori M, Vlassara H (2000) Differential expression of renal AGE-receptor genes in NOD mice: possible role in nonobese diabetic renal disease. Kidney Internat 58: 1931-1940

86. Park L, Raman KG, Lee KJ et al. (1998) Suppression of accelerated diabetic atherosclerosis by the soluble receptor for advanced glycation endproducts. Nat Med 4: $1025-1031$

87. Tanji N, Markowitz GS, Fu CF et al. (2000) Expression of advanced glycation end products and their cellular receptor RAGE in diabetic nephropathy and nondiabetic renal disease. J Am Soc Nephrol 11: 1656-1666

88. Soulis T, Thallas V, Youssef S et al. (1997) Advanced glycation end products and the receptor for advanced glycated end products co-localise in organs susceptible to diabetic microvascular injury: immunohistochemical studies. Diabetologia 40: 619-628 
89. Youssef S, Nguyen DT, Soulis T, Panagiotopoulos S, Jerums G, Cooper ME (1999) Effect of diabetes and aminoguanidine therapy on renal advanced glycation end-product binding. Kidney Int 55: 907-916

90. Kelly DJ, Gilbert RE, Cox AJ, Soulis T, Jerums G, Cooper ME (2001) Aminoguanidine ameliorates overexpression of prosclerotic growth factors and collagen deposition in experimental diabetic nephropathy. JASN 10: 2098-2107

91. Tsuchida K, Makita Z, Yamagishi S et al. (1999) Suppression of transforming growth factor beta and vascular endothelial growth factor in diabetic nephropathy in rats by a novel advanced glycation end product inhibitor, OPB9195. Diabetologia 42: 579-588

92. Oates PJ, Mylari BL (1999) Aldose reductase inhibitors: therapeutic implications for diabetic complications. Expert Opin Investig Drugs 8: 2095-2119

93. Dunlop M (2000) Aldose reductase and the role of the polyol pathway in diabetic nephropathy. Kidney Internat 58: S3-S12

94. Greene DA, Lattimer SA, Sima AAF (1987) Sorbitol, phosphoinositides, and sodium-potassium-ATPase in the pathogenesis of diabetic complications. N Engl J Med 316: 599-606

95. Ishii H, Tada H, Isogai S (1998) An aldose reductase inhibitor prevents glucose-induced increase in transforming growth factor-beta and protein kinase c activity in cultured human mesangial cells. Diabetologia 41: 362-364

96. Chang WP, Dimitriadis E, Allen T, Dunlop ME, Cooper M, Larkins RG (1991) The effect of aldose reductase inhibitors on glomerular prostaglandin production and urinary albumin excretion in experimental diabetes mellitus. Diabetologia 34: 225-231

97. Bank N, Mower P, Aynedjian H, Wilkes B, Silverman S (1989) Sorbinil prevents glomerular hyperperfusion in diabetic rats. Am J Physiol 256: F1000-F1006

98. Mauer SM, Steffes MW, Azar S, Brown DM (1989) Effects of sorbinil on glomerular structure and function in long-term- diabetic rats. Diabetes 38: 839-846

99. McAuliffe AV, Brooks BA, Fisher EJ, Molyneaux LM, Yue DK (1998) Administration of ascorbic acid and an aldose reductase inhibitor (Tolrestat) in diabetes - effect on urinary albumin excretion. Nephron 80: 277-284

100. Pedersen MM, Christiansen JS, Mogensen CE (1991) Reduction of glomerular hyperfiltration in normoalbuminuric IDDM patients by 6 mo of aldose reductase inhibition. Diabetes 40: 527-531

101. Schleicher ED, Weigert C (2000) Role of the hexosamine biosynthetic pathway in diabetic nephropathy. Kidney Int 58: S13-S18

102. James LR, Fantus IG, Goldberg H, Ly H, Scholey JW (2000) Overexpression of GFAT activates PAI-1 promoter in mesangial cells. Am J Physiol - Renal Physiol 279: F718-F727

103. Weigert C, Brodbeck K, Lehmann R, Haring HU, Schleicher ED (2001) Overexpression of glutamine : fructose6-phosphate-amidotransferase induces transforming growth factor-beta 1 synthesis in NIH-3T3 fibroblasts. FEBS Lett 488: 95-99

104. Heilig CW, Concepcion LA, Riser BL, Freytag SO, Zhu M, Cortes P (1995) Overexpression of glucose transporters in rat mesangial cells cultured in a normal glucose milieu mimics the diabetic phenotype. J Clin Invest 96: 1802-1814

105. Heilig CW, Liu Y, England RL et al. (1997) D-glucose stimulates mesangial cell GLUT1 expression and basal and IGF- I-sensitive glucose uptake in rat mesangial cells: implications for diabetic nephropathy. Diabetes 46: 1030-1039

106. Henry DN, Busik JV, Brosius FC 3rd, Heilig CW (1999) Glucose transporters control gene expression of aldose reductase, PKCalpha, and GLUT1 in mesangial cells in vitro. Am J Physiol 277: F97-F104

107. Heilig CW, Kreisberg JI, Freytag S et al. (2001) Antisense GLUT-1 protects mesangial cells from glucose induction of GLUT-1 and fibronectin expression. Am J Physiol Renal Physiol 280: F657-F666

108. Chin E, Zamah AM, Landau D et al. (1997) Changes in facilitative glucose transporter messenger ribonucleic acid levels in the diabetic rat kidney. Endocrinology 138: 1267-1275

109. Nishikawa T, Edelstein D, Du XL et al. (2000) Normalizing mitochondrial superoxide production blocks three pathways of hyperglycaemic damage. Nature 404: 787-790

110. Soulis LT, Cooper ME, Dunlop M and Jerums G (1995) The relative roles of advanced glycation, oxidation and aldose reductase inhibition in the development of experimental diabetic nephropathy in the Sprague-Dawley rat. Diabetologia 38: 387-394

111. Ha H, Lee HB (2000) Reactive oxygen species as glucose signaling molecules in mesangial cells cultured under high glucose. Kidney Int 58: 19-25

112. Scivittaro V, Ganz MB, Weiss MF (2000) AGEs induce oxidative stress and activate protein kinase C-beta(II) in neonatal mesangial cells. Am J Physiol Renal Physiol 278: F676-F683

113. Ha H, Endou H (1992) Lipid peroxidation in isolated rat nephron segments. Am J Physiol 263: F201-F207

114. Han HJ, Choi HJ, Park SH (2000) High glucose inhibits glucose uptake in renal proximal tubule cells by oxidative stress and protein kinase C. Kidney Int 57: 918-926

115. Chen HC, Guh JY, Shin SJ, Tsai JH, Lai YH (2000) Reactive oxygen species enhances endothelin-1 production of diabetic rat glomeruli in vitro and in vivo. $\mathrm{J}$ Lab Clin Med 135: 309-315

116. Xia P, Inoguchi T, Kern TS, Engerman RL, Oates PJ, King GL (1994) Characterization of the mechanism for the chronic activation of diacylglycerol-protein kinase c pathway in diabetes and hypergalactosemia. Diabetes 43: 1122-1129

117. Studer RK, Craven PA, Derubertis FR (1993) Activation of protein kinase-c reduces thromboxane receptors in glomeruli and mesangial cells. Kidney Int 44: 58-64

118. Koya D, Jirousek MR, Lin YW, Ishii H, Kuboki K, King GL (1997) Characterization of protein kinase c beta isoform activation on the gene expression of transforming growth factor-beta, extracellular matrix components, and prostanoids in the glomeruli of diabetic rats. J Clin Invest 100: $115-126$

119. Ishii H, Jirousek MR, Koya D et al. (1996) Amelioration of vascular dysfunctions in diabetic rats by an oral PKC beta inhibitor. Science 272: 728-731

120. Koya D, Haneda M, Nakagawa H et al. (2000) Amelioration of accelerated diabetic mesangial expansion by treatment with a PKC beta inhibitor in diabetic $\mathrm{db} / \mathrm{db}$ mice, a rodent model for type 2 diabetes. FASEB J 14: 439-447

121. Osicka TM, Yu YX, Panagiotopoulos S et al. (2000) Prevention of albuminuria by aminoguanidine or ramipril in streptozotocin-induced diabetic rats is associated with the normalization of glomerular protein kinase C. Diabetes 49: 87-93

122. Osicka TM, Yu YX, Lee V, Panagiotopoulos S, Kemp BE, Jerums G (2001) Aminoguanidine and ramipril prevent diabetes-induced increases in protein kinase $\mathrm{C}$ activity in 
glomeruli, retina and mesenteric artery. Clin Sci (Colch) 100: 249-257

123. Aiello LP, Bursell SE, Clermont A et al. (1997) Vascular endothelial growth factor-induced retinal permeability is mediated by protein kinase $\mathrm{c}$ in vivo and suppressed by an orally effective beta-isoform-selective inhibitor. Diabetes 46: $1473-1480$

124. Cha DR, Kim NH, Yoon JW et al. (2000) Role of vascular endothelial growth factor in diabetic nephropathy. Kidney Int 58: S104-S112

125. Studer RK, Craven PA, Derubertis FR (1997) Antioxidant inhibition of protein kinase $\mathrm{c}$ signaled increases in transforming growth factor-beta in mesangial cells. Metabolism 46: 918-925

126. Barnes PJ, Larin M (1997) Mechanisms of disease - nuclear factor-kappa-b - a pivotal transcription factor in chronic inflammatory diseases [review]. $\mathrm{N}$ Engl J Med 336: 1066-1071

127. Pieper GM, Riaz-ul-Haq (1997) Activation of nuclear factor-kappa-b in cultured endothelial cells by increased glucose concentration - prevention by Calphostin C. J Cardiovasc Pharmacol 30: 528-532

128. Li JF, Schmidt AM (1997) Characterization and functional analysis of the promoter of rage, the receptor for advanced glycation end products. J Biol Chem 272: 16498-16506

129. Rangan GK, Wang YP, Tay YC, Harris DCH (1999) Inhibition of nuclear factor-kappa $\mathrm{B}$ activation reduces cortical tubulointerstitial injury in proteinuric rats. Kidney Int 56: $118-134$

130. Tomlinson DR (1999) Mitogen-activated protein kinases as glucose transducers for diabetic complications [Review]. Diabetologia 42: 1271-1281

131. Choi ME (2000) Mechanism of transforming growth factor-beta 1 signaling: Role of the mitogen-activated protein kinase. Kidney Int 58: S53-S58

132. Igarashi M, Wakasaki H, Takahara N et al. (1999) Glucose or diabetes activates p38 mitogen-activated protein kinase via different pathways. J Clin Invest 103: 185-195

133. Dunlop ME, Muggli EE (2000) Small heat shock protein alteration provides a mechanism to reduce mesangial cell contractility in diabetes and oxidative stress. Kidney Int 57: 464-475

134. Haneda M, Araki S, Togawa M, Sugimoto T, Isono M, Kikkawa R (1997) Mitogen-activated protein kinase cascade is activated in glomeruli of diabetic rats and glomerular mesangial cells cultured under high glucose conditions. Diabetes 46: 847-853

135. Lander HM, Tauras JM, Ogiste JS, Hori O, Moss RA, Schmidt AM (1997) Activation of the receptor for advanced glycation end products triggers a p21(ras)-dependent mitogen-activated protein kinase pathway regulated by oxidant stress. J Biol Chem 272: 17810-17814

136. Kang MJ, Wu XY, Ly H, Thai K, Scholey JW (1999) Effect of glucose on stress-activated protein kinase activity in mesangial cells and diabetic glomeruli. Kidney Int 55: 2203-2214

137. Zhang SL, Tang SS, Chen X, Filep JG, Ingelfinger JR, Chan JSD (2000) High levels of glucose stimulate angiotensinogen gene expression via the $\mathrm{p} 38$ mitogen-activated protein kinase pathway in rat kidney proximal tubular cells. Endocrinology 141: 4637-4646

138. Inoki K, Haneda M, Ishida T et al. (2000) Role of mitogen-activated protein kinases as downstream effectors of transforming growth factor-beta in mesangial cells. Kidney Int 58: S76-S80
139. Massague J (1998) TGF-beta signal transduction [review]. Annu Rev Biochem 67: 753-791

140. Schiffer M, Von Gersdorff G, Bitzer M, Susztak K, Bottinger EP (2000) Smad proteins and transforming growth factor-beta signaling. Kidney Int 58: 45-52

141. Border WA, Noble NA (1994) Transforming growth factor beta in tissue fibrosis [Review]. N Engl J Med 331: $1286-1292$

142. Rocco MV, Chen Y, Goldfarb S, Ziyadeh FN (1992) Elevated glucose stimulates TGF-beta gene expression and bioactivity in proximal tubule. Kidney Int 41: 107-114

143. Rumble JR, Cooper ME, Soulis T et al. (1997) Vascular hypertrophy in experimental diabetes: role of advanced glycation end products. J Clin Invest 99: 1016-1027

144. Gruden G, Thomas S, Burt D et al. (1999) Interaction of angiotensin II and mechanical stretch on vascular endothelial growth factor production by human mesangial cells. J Am Soc Nephrol 10: 730-737

145. Wolf G, Ziyadeh FN, Zahner G, Stahl RAK (1995) Angiotensin II-stimulated expression of transforming growth factor beta in renal proximal tubular cells - attenuation after stable transfection with the C-mas oncogene. Kidney Int 48: 1818-1827

146. Herman WH, Emancipator SN, Rhoten RLP, Simonson MS (1998) Vascular and glomerular expression of endothelin-1 in normal human kidney. Am J Physiol Renal Physiol 44: F8-F17

147. Jandeleit-Dahm K, Cao ZM, Cox AJ, Kelly DJ, Gilbert RE, Cooper ME (1999) Role of hyperlipidemia in progressive renal disease: focus on diabetic nephropathy. Kidney Int 56: S31-S36

148. Montero A, Munger KA, Khan RZ et al. (2000) F-2-isoprostanes mediate high glucose-induced TGF-beta synthesis and glomerular proteinuria in experimental type I diabetes. Kidney Int 58: 1963-1972

149. Chen S, Cohen MP, Lautenslager GT, Shearman CW, Ziyadeh FN (2001) Glycated albumin stimulates TGF-beta 1 production and protein kinase $\mathrm{C}$ activity in glomerular endothelial cells. Kidney Int 59: 673-681

150. Poczatek MH, Hugo C, Darley-Usmar V, Murphy-Ullrich JE (2000) Glucose stimulation of transforming growth factor-beta bioactivity in mesangial cells is mediated by thrombospondin-1. Am J Pathol 157: 1353-1363

151. McMahon R, Murphy M, Clarkson M et al. (2000) IHG-2, a mesangial cell gene induced by high glucose, is human gremlin - regulation by extracellular glucose concentration, cyclic mechanical strain, and transforming growth factor-beta 1. J Biol Chem 275: 9901-9904

152. Lang F, Klingel K, Wagner CA et al. (2000) Deranged transcriptional regulation of cell-volume-sensitive kinase hSGK in diabetic nephropathy. Proc Natl Acad Sci USA 97: 8157-8162

153. Yamamoto T, Nakamura T, Noble NA, Ruoslahti E, Border WA (1993) Diabetic kidney disease is linked to elevated expression of transforming growth factor- $\beta$. Proc Natl Acad Sci USA 90: 1814-1818

154. Gilbert RE, Wilkinson-Berka JL, Johnson DW et al. (1998) Renal expression of transforming growth factorbeta inducible gene-h3 (beta-Ig-H3) in normal and diabetic rats. Kidney Int 54: 1052-1062

155. Ceol M, Gambaro G, Sauer U et al. (2000) Glycosaminoglycan therapy prevents TGF-beta 1 overexpression and pathologic changes in renal tissue of long-term diabetic rats. J Am Soc Nephrol 11: 2324-2336

156. Hill C, Flyvbjerg A, Gronbaek H et al. (2000) The renal expression of transforming growth factor-beta isoforms 
and their receptors in acute and chronic experimental diabetes in rats. Endocrinology 141: 1196-1208

157. Isono M, Mogyorosi A, Han DC, Hoffman BB, Ziyadeh FN (2000) Stimulation of TGF-beta type II receptor by high glucose in mouse mesangial cells and in diabetic kidney. Am J Physiol Physiol 278: F830-F838

158. Hill C, Logan A, Smith C, Gronbaek H, Flyvbjerg A (2001) Angiotensin converting enzyme inhibitor suppresses glomerular transforming growth factor beta receptor expression in experimental diabetes in rats. Diabetologia 44: 495-500

159. Isaka Y, Fujiwara Y, Ueda N, Kaneda Y, Kamada T, Imai E (1993) Glomerulosclerosis induced by in vivo transfection of transforming growth factor-beta or platelet-derived growth factor gene into the rat kidney. J Clin Invest 92: 2597-2601

160. Nakamura T, Ebihara I, Fukui M, Tomino Y, Koide H (1995) Effect of a specific endothelin receptor a antagonist on mrna levels for extracellular matrix components and growth factors in diabetic glomeruli. Diabetes 44: 895-899

161. Buchdunger E, Zimmermann J, Mett H et al. (1995) Selective Inhibition of the platelet-derived growth factor signal transduction pathway by a protein-tyrosine kinase inhibitor of the 2-phenylaminopyrimidine class. Proc Nat Acad Sci USA 92: 2558-2562

162. Gilbert RE, Kelly DJ, McKay T et al. (2001) PDGF signal transduction inhibition ameliorates experimental mesangial proliferative glomerulonephritis. Kidney Int 59: 1324-1332

163. Riser BL, Denichilo M, Cortes P et al. (2000) Regulation of connective tissue growth factor activity in cultured rat mesangial cells and its expression in experimental diabetic glomerulosclerosis. J Am Soc Nephrol 11: 25-38

164. Twigg SM, Chen MM, Joly AH et al. (2001) Connective tissue growth factor/IGFBP-rP2 is up-regulated by advanced glycosylatiuon end-products in human fibroblasts: a potential mechanism for expansion of extracellular matrix in diabetes mellitus. Endocrinology 142: 1760-1769

165. Aiello LP, Avery RL, Arrigg PG et al. (1994) Vascular endothelial growth factor in ocular fluid of patients with diabetic retinopathy and other retinal disorders. N Engl J Med 331: 1480-1487

166. Cooper ME, Vranes D, Youssef S et al. (1999) Increased renal expression of vascular endothelial growth factor (VEGF) and its receptor VEGFR-2 in experimental diabetes. Diabetes 48: 2229-2239

167. De Vriese AS, Tilton RG, Elger M, Stephan CC, Kriz W, Lameire NH (2001) Antibodies against vascular endothelial growth factor improve early renal dysfunction in experimental diabetes. J Am Soc Nephrol 12: 993-1000

168. Kim NH, Jung HH, Cha DR, Choi DS (2000) Expression of vascular endothelial growth factor in response to high glucose in rat mesangial cells. J Endocrinol 165: 617-624

169. Lu M, Kuroki M, Amano S et al. (1998) Advanced glycation end products increase retinal vascular endothelial growth factor expression. J Clin Invest 101: 1219-1224

170. Williams B, Baker AQ, Gallacher B, Lodwick D (1995) Angiotensin II increases vascular permeability factor gene expression by human vascular smooth muscle cells. Hypertension 25: 913-917

171. Gruden G, Thomas S, Burt D et al. (1997) Mechanical stretch induces vascular permeability factor in human mesangial cells - mechanisms of signal transduction. Proc Natl Acad Sci USA 94: 12112-12116

172. Gilbert RE, Kelly DJ, Cox AJ et al. (2000) Angiotensin converting enzyme inhibition reduces retinal overexpression of vascular endothelial growth factor and hyperpermeability in experimental diabetes. Diabetologia 43: 1360-1367

173. Moravski CJ, Kelly DJ, Cooper ME et al. (2000) Retinal neovascularization is prevented by blockade of the reninangiotensin system. Hypertension 36: 1099-1104

174. Gilbert RE, Cox A, McNally PG et al. (1997) Increased epidermal growth factor in experimental diabetes related kidney growth in rats. Diabetologia 40: 778-785

175. Flyvbjerg A, Landau D, Domene H, Hernandez L, Gronbaek H, Leroith D (1995) The role of growth hormone, insulin-like growth factors (Igfs), and Igf-binding proteins in experimental diabetic kidney disease. Metabolism 44: 67-71

176. Raz I, Rubinger D, Popovtzer M, Gronbaek H, Weiss O, Flyvbjerg A (1998) Octreotide prevents the early increase in renal insulin-like growth factor binding protein 1 in streptozotocin diabetic rats. Diabetes 47: 924-930

177. Bach LA, Cox AJ, Mendelsohn FA, Herington AC, Werther GA, Jerums G (1992) Focal induction of IGF binding proteins in proximal tubules of diabetic rat kidney. Diabetes 41: 499-507

178. Ruotsalainen V, Ljungberg P, Wartiovaara J et al. (1999) Nephrin is specifically located at the slit diaphragm of glomerular podocytes. Proc Natl Acad Sci USA 96: $7962-7967$

179. Kawachi H, Koike H, Kurihara H et al. (2000) Cloning of rat nephrin: expression in developing glomeruli and in proteinuric states. Kidney Int 57: 1949-1961

180. Bonnet F, Cooper ME, Kawachi H, Allen TJ, Boner G, Cao Z (2001) Irbesartan normalises the deficiency in glomerular nephrin expression in a model of diabetes and hypertension. Diabetologia 44: 874-877

181. Benigni A, Tomasoni S, Gagliardini E et al. (2001) Blocking angiotensin II synthesis/activity preserves glomerular nephrin in rats with severe nephrosis. J Am Soc Nephrol 12: $941-948$

182. Furness PN, Hall LL, Shaw JA, Pringle JH (1999) Glomerular expression of nephrin is decreased in acquired human nephrotic syndrome. Nephrol Dial Transplant 14: 1234-1237

183. Johnson RJ (2000) New insights into the pathogenesis of proteinuria. Am J Kidney Dis 36: 214-219

184. Bakris GL, Williams M, Dworkin L et al. (2000) Preserving renal function in adults with hypertension and diabetes: a consensus approach. Am J Kidney Disease 36: 646-661

185. Wada J, Zhang H, Tsuchiyama Y et al. (2001) Gene expression profile in streptozotocin-induced diabetic mice kidneys undergoing glomerulosclerosis. Kidney Int 59: 1363-1373 